\title{
Evaluasi kinerja PDAM Tirta Jasa di Kabupaten Lampung Selatan
}

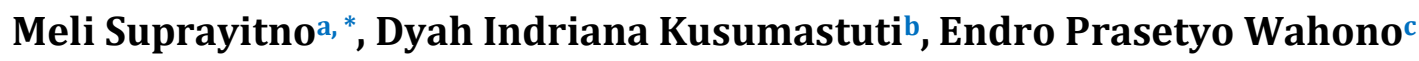 \\ ${ }^{a}$ Mahasiswa Magister Teknik Sipil, Universitas Lampung, Jl. Soemantri Brojonegoro No. 1 Bandar Lampung, 35145, Indonesia \\ ${ }^{b}$ Jurusan Teknik Sipil, Universitas Lampung, Jl. Soemantri Brojonegoro No. 1 Bandar Lampung, 35145, Indonesia \\ c Jurusan Teknik Sipil, Universitas Lampung, Jl. Soemantri Brojonegoro No. 1 Bandar Lampung, 35145, Indonesia
}

\section{H I G H L I G H T S}

- Penilaian kinerja PDAM Tirta Jasa di Kabupaten Lampung Selatan telah dilakukan menggunakan empat aspek yaitu aspek keuangan, pelayanan, operasional, sumber daya manusia dan delapan belas indikator penilaian kinerja, untuk kurun waktu 2014-2018.

- Hasil penilaian empat aspek selanjutnya telah dikelompokkan dalam tiga kategori kinerja PDAM yaitu sehat dengan nilai > 2,8; kurang sehat, dengan nilai 2,2 - 2,8 dan sakit dengan nilai $<2,2$.

\section{N F O A R T I K E L}

\section{Riwayat artikel:}

Diterima 17 Maret 2021

Diterima setelah diperbaiki 18 Mei 2021

Diterima untuk diterbitkan 20 Juli 2021

Tersedia secara online 1 Agustus 2021

\section{Kata kunci:}

Evaluasi kinerja,

penyediaan air minum,

perusahaan daerah air minum,

Tirta Jasa Lampung Selatan.

\begin{abstract}
A B S T R A K
Pengembangan Sistem Penyediaan Air Minum (SPAM) merupakan kegiatan yang bertujuan membangun, memperluas dan meningkatkan sistem fisik dan non fisik dalam kesatuan yang utuh untuk melaksanakan penyediaan air minum kepada masyarakat menuju keadaan yang lebih baik. Sebagai salah satu penyelenggaran SPAM, PDAM dituntut untuk mampu memberikan pelayanan penyediaan air bersih yang sebaik-baiknya kepada masyarakat, disamping mencari keuntungan untuk membiayai serta menghidupi kelangsungan perusahaan itu sendiri. Untuk mengetahui kualitas pelayanan tersebut, perlu dipantau dan dievaluasi melalui suatu ukuran tingkat keberhasilan pengelolaan terhadap kinerjanya. Kegiatan kajian evaluasi kinerja PDAM Tirta Jasa Kabupaten Lampung Selatan secara garis besar dilakukan melalui tahapan inventarisasi data; verifkasi, validasi dan updating; evaluasi kinerja PDAM dan penetapan status kinerja PDAM. Penilaian kinerja PDAM menggunakan empat aspek yaitu aspek keuangan, pelayanan, operasional, sumber daya manusia dan delapan belas indikator penilaian kinerja. Bobot aspek keuangan 25\%, aspek pelayanan 25\%, aspek operasional 35\%, dan aspek sumber daya manusia $15 \%$. Hasil penilaian empat aspek tersebut selanjutnya dikelompokkan dalam 3 (tiga) kategori kinerja PDAM yaitu: Sehat, dengan nilai > 2,8; Kurang Sehat, dengan nilai 2,2 - 2,8; dan Sakit, dengan nilai $<2,2$.
\end{abstract}

Diterbitkan oleh Jurusan Teknik Sipil Universitas Lampung

\section{Pendahuluan}

Dalam Peraturan Pemerintah Nomor 16 Tahun 2005, disebutkan bahwa pengembangan Sistem Penyediaan Air Minum (SPAM) adalah kegiatan yang bertujuan untuk membangun, memperluas dan/atau meningkatkan sistem fisik (teknik) dan non fisik (kelembagaan, manajemen, keuangan, peran serta masyarakat, dan hukum) dalam kesatuan yang utuh untuk melaksanakan penyediaan air minum kepada masyarakat menuju keadaan yang lebih baik. Di dalam pelaksanaannya, pengembangan SPAM dilakukan oleh Perusahaan Daerah Air Minum (PDAM) yang merupakan salah satu penyelenggara SPAM. PDAM merupakan badan

\footnotetext{
* Penulis koresponden.

Alamat e-mail: suprayitnom@gmail.com (M. Suprayitno)

Peer review dibawah tanggung-jawab Jurusan Teknik Sipil Universitas Lampung.

https://doi.org/10.23960/rekrjits.v25i2.39
}

usaha milik daerah, yang pendiriannya diprakarsai oleh pemerintah daerah dan seluruh atau sebagian besar modalnya dimiliki oleh daerah melalui penyertaan secara langsung yang berasal dari kekayaan daerah yang dipisahkan yang dibentuk khusus sebagai Penyelenggara (PP Nomor 16 Tahun 2005).

Sebagai salah satu perusahaan yang dimiliki oleh daerah, PDAM dituntut untuk mampu memberikan pelayanan penyediaan air bersih yang sebaik-baiknya kepada masyarakat, disamping mencari keuntungan untuk membiayai serta menghidupi kelangsungan perusahaan itu sendiri [1]. Untuk mengetahui kualitas pelayanan tersebut, perlu dipantau dan dievaluasi melalui suatu ukuran tingkat keberhasilan pengelolaan terutama dalam hal antara lain: capaian pelayanan air minum kepada masyarakat baik kualitas, kuantitas maupun kontinuitas, capaian pengelolaan keuangan secara prinsip ekonomi yang sehat dan berkelanjutan, capaian operasional teknis sesuai dengan 
NSPM yang seharusnya dan capaian pertumbuhan organisasi secara profesional.

Tingkat keberhasilan capaian pengelolaan SPAM oleh PDAM tersebut, dapat diukur melalui penilaian terhadap kinerjanya [2]. Penilaian kinerja PDAM penyelenggara SPAM merupakan upaya untuk melihat dan mengukur tingkat kinerja manajemen dalam mengelola perusahaan yang bertujuan untuk mengetahui sejauh mana efisiensi dan efektifitas pengelolaannya [3]. Penilaian kinerja PDAM didasarkan pada empat aspek kinerja yaitu aspek keuangan, aspek pelayanan, aspek operasional dan aspek sumber daya manusia. Masing-masing aspek tersebut dirinci ke dalam beberapa indikator penilaian dengan tujuan untuk lebih memberikan kecermatan dalam melakukan penilaian. Hasil penilaian kinerja diklasifkasikan ke dalam tiga kategori, yaitu: PDAM sehat, PDAM kurang sehat dan PDAM sakit.

Huda [4] mengungkapkan bahwa PDAM sehat adalah PDAM yang mampu berkembang, memperbaiki kas dan kewajiban pinjaman, mampu mengoperasikan instalasi secara efisien dan efektif serta memberikan pelayanan yang prima kepada masyarakat secara tepat kualitas, kuantitas dan kontinuitas.

\section{Metode Penelitian}

Kegiatan kajian kinerja PDAM dilakukan melalui tahapan seperti berikut: (1) inventarisasi data, berisi langkah pengumpulan data disesuaikan dengan aspek-aspek indikator kinerja yaitu aspek keuangan, aspek pelayanan, aspek operasional, dan aspek sumber daya manusia, (2) verifikasi, validasi dan updating, berisi langkah untuk mendapatkan data-data terkini yang bersifat valid dan terverifkasi sehingga akan diperoleh hasil evaluasi yang on the track dan seragam, (3) formula evaluasi kinerja PDAM, tahap ini berisi langkah memasukkan data-data yang telah terkumpul ke dalam rumus-rumus perhitungan indikator kinerja. Perhitungan nilai indikator kinerja didasarkan pada bobot dan nilai standar/kriteria masing-masing indikator sehingga nantinya akan diperoleh nilai total kinerja. (4) penetapan status kinerja, dilakukan dengan membandingkan nilai total kinerja yang diperoleh dengan kriteria yang telah ditetapkan, yaitu sehat, kurang sehat dan sakit dengan uraian seperti berikut: kinerja PDAM sehat, apabila memiliki nilai total kinerja > 2,8; kinerja PDAM kurang sehat, apabila memiliki nilai total kinerja 2,2 - 2,8; kinerja PDAM sakit, apabila memiliki nilai total kinerja $<2,2$. Tahapan yang dilakukan untuk menentukan kinerja PDAM adalah inventarisasi data, evaluasi kinerja dan penetapan status kinerja, dijelaskan sebagai berikut.

Untuk tahap inventarisasi data, pengumpulan data yang nantinya menjadi input dalam proses evaluasi kinerja PDAM disajikan pada Tabel 1. Selanjutnya dilakukan evaluasi kinerja, yaitu untuk aspek keuangan, yang dievaluasi adalah rentabilitas, likuiditas dan solvabilitas. Rentabilitas terdiri dari return of equity yaitu yang memiliki pengertian sebagai suatu rasio untuk mengukur tingkat kemampuan memperoleh laba dari modal (ekuitas) yang ada (Persamaan 1) dan rasio operasi yang memiliki pengertian sebagai suatu rasio untuk mengukur tingkat efisiensi beban yang dikeluarkan untuk menghasilkan pendapatan (Persamaan 2). Sedangkan likuiditas terdiri dari rasio kas, yang memiliki pengertian sebagai suatu rasio untuk mengukur kemampuan kas dalam rangka menjamin kewajiban jangka pendek (Persamaan 3), dan efektivitas penagihan, yang memiliki pengertian sebagai ukuran dalam menakar efektifitas kegiatan penagihan atas hasil penjualan air (Persamaan 4).
Tabel 1

Kebutuhan data evaluasi kinerja PDAM [5]

\begin{tabular}{|c|c|c|}
\hline $\begin{array}{l}\text { Kelompok } \\
\text { data }\end{array}$ & $\begin{array}{l}\text { Data yang } \\
\text { diperlukan }\end{array}$ & Sumber data \\
\hline \multicolumn{3}{|c|}{ A. Aspek keuangan } \\
\hline $\begin{array}{l}\text { Return on } \\
\text { equity (ROE) }\end{array}$ & $\begin{array}{l}\text { - Laba bersih setelah } \\
\text { pajak } \\
\text { - Jumlah ekuitas } \\
\text { (modal + cadangan) }\end{array}$ & $\begin{array}{l}\text { - Laporan keuangan yang } \\
\text { telah diaudit KAP, BPK } \\
\text { atau BPKP; } \\
\text { - Laporan keuangan } \\
\text { internal PDAM pada } \\
\text { tahun berjalan. }\end{array}$ \\
\hline Rasio operasi & $\begin{array}{l}\text { - Jumlah beban } \\
\text { operasi; } \\
\text { - Jumlah pendapatan } \\
\text { operasi }\end{array}$ & $\begin{array}{l}\text { - Laporan keuangan yang } \\
\text { telah diaudit KAP, BPK } \\
\text { atau BPKP; } \\
\text { - Laporan keuangan } \\
\text { internal PDAM pada } \\
\text { tahun berjalan. }\end{array}$ \\
\hline Rasio kas & $\begin{array}{l}\text { - Jumlah kas + setara } \\
\text { kas; } \\
\text { - Jumlah kewajiban } \\
\text { lancar }\end{array}$ & $\begin{array}{l}\text { - Laporan keuangan yang } \\
\text { telah diaudit oleh KAP, } \\
\text { BPK atau BPKP; } \\
\text { - Laporan keuangan } \\
\text { internal PDAM pada } \\
\text { tahun berjalan. }\end{array}$ \\
\hline $\begin{array}{l}\text { Efektivitas } \\
\text { penagihan }\end{array}$ & $\begin{array}{l}\text { - Jumlah } \\
\text { penerimaan } \\
\text { rekening air; } \\
\text { - Jumlah rekening } \\
\text { air }\end{array}$ & $\begin{array}{l}\text { - Laporan Daftar Rekening } \\
\text { Ditagih (DRD); } \\
\text { - Laporan Arus Kas }\end{array}$ \\
\hline Solvabilitas & $\begin{array}{l}\text { - Jumlah aset; } \\
\text { • Jumlah kewajiban }\end{array}$ & $\begin{array}{l}\text { - Laporan keuangan yang } \\
\text { telah diaudit oleh KAP, } \\
\text { BPK atau BPKP; } \\
\text { • Laporan keuangan } \\
\text { internal PDAM pada } \\
\text { tahun berjalan. }\end{array}$ \\
\hline
\end{tabular}

\section{B. Aspek pelayanan}

\begin{tabular}{|c|c|c|}
\hline $\begin{array}{l}\text { Cakupan } \\
\text { pelayanan } \\
\text { teknis }\end{array}$ & $\begin{array}{l}\text { • Jumlah penduduk } \\
\text { terlayani; } \\
\text { •Jumlah penduduk } \\
\text { di wilayah } \\
\text { pelayanan teknis. }\end{array}$ & $\begin{array}{l}\text { - Laporan teknik dan atau } \\
\text { laporan bagian pelayanan } \\
\text { - Kabupaten/kota dan atau } \\
\text { kecamatan dalam angka } \\
\text { yang diambil dari BPS. }\end{array}$ \\
\hline $\begin{array}{l}\text { Pertumbuhan } \\
\text { pelanggan }\end{array}$ & $\begin{array}{l}\text {-Jumlah pelanggan } \\
\text { periode ini; } \\
\text { •Jumlah pelanggan } \\
\text { periode lalu. }\end{array}$ & $\begin{array}{l}\text { Rekapitulasi jumlah } \\
\text { pelanggan yang } \\
\text { tercantum di dalam } \\
\text { daftar pelanggan pada } \\
\text { bagian hubungan } \\
\text { langganan }\end{array}$ \\
\hline $\begin{array}{l}\text { Tingkat } \\
\text { penyelesaian } \\
\text { pengaduan }\end{array}$ & $\begin{array}{l}\text {-Jumlah pengaduan } \\
\text { pelanggan } \\
\text { tertangani; } \\
\text { •Jumlah } \\
\text { pengaduan. }\end{array}$ & $\begin{array}{l}\text { Daftar keluhan } \\
\text { pelanggan yang tercatat } \\
\text { di bagian hubungan } \\
\text { pelanggan atau bagian } \\
\text { pelayanan pelanggan. }\end{array}$ \\
\hline $\begin{array}{l}\text { Kualitas air } \\
\text { pelanggan }\end{array}$ & $\begin{array}{l}\text { Hasil pengujian } \\
\text { kualitas air di } \\
\text { sambungan } \\
\text { pelanggan. }\end{array}$ & $\begin{array}{l}\text { - Laporan hasil uji } \\
\text { laboratorium internal } \\
\text { • Laporan hasil uji } \\
\text { laboratorium eksternal }\end{array}$ \\
\hline $\begin{array}{l}\text { Konsumsi air } \\
\text { domestik }\end{array}$ & $\begin{array}{l}\text { - Rata-rata jumlah } \\
\text { air terjual } \\
\text { pelanggan } \\
\text { domestik per } \\
\text { bulan; } \\
\text {-Jumlah pelanggan } \\
\text { domestik aktif }\end{array}$ & $\begin{array}{l}\text { Ikhtisar Rekening Air } \\
\text { (IRA) atau laporan } \\
\text { pemakaian rata-rata air } \\
\text { pelanggan; }\end{array}$ \\
\hline \multicolumn{3}{|c|}{ C. Data aspek operasional } \\
\hline $\begin{array}{l}\text { Efsiensi } \\
\text { produksi }\end{array}$ & $\begin{array}{l}\text { - Realisasi produksi } \\
\text { air atau volume } \\
\text { produksi riil; } \\
\text { - Kapasitas terpasang }\end{array}$ & $\begin{array}{l}\text { Laporan teknik (bagian } \\
\text { produksi) }\end{array}$ \\
\hline
\end{tabular}


Tabel 1 (Lanjutan)

Kebutuhan data evaluasi kinerja PDAM [5]

\begin{tabular}{|c|c|c|}
\hline $\begin{array}{l}\text { Kelompok } \\
\text { data }\end{array}$ & $\begin{array}{l}\text { Data yang } \\
\text { diperlukan }\end{array}$ & Sumber data \\
\hline $\begin{array}{l}\text { Air tak } \\
\text { berekening } \\
\text { (ATR) }\end{array}$ & $\begin{array}{l}\text {-Volume distribusi } \\
\text { air; } \\
\text { •Volume air terjual }\end{array}$ & $\begin{array}{l}\text { - Laporan teknik } \\
\text { (bagian distribusi); } \\
\text { - Ikhtisar rekening air }\end{array}$ \\
\hline $\begin{array}{l}\text { Jam operasi } \\
\text { layanan }\end{array}$ & $\begin{array}{l}\text { Waktu distribusi air } \\
\text { ke pelanggan }\end{array}$ & $\begin{array}{l}\text { Laporan teknik (bagian } \\
\text { distribusi) }\end{array}$ \\
\hline $\begin{array}{l}\text { Tekanan air } \\
\text { pada } \\
\text { sambungan } \\
\text { pelanggan }\end{array}$ & $\begin{array}{l}\text { • Jumlah pelanggan } \\
\text { terlayani dengan } \\
\text { tekanan minimal } \\
0.7 \text { bar; } \\
\text { •Jumlah pelanggan. }\end{array}$ & $\begin{array}{l}\text { Laporan teknik (bagian } \\
\text { distribusi) }\end{array}$ \\
\hline $\begin{array}{l}\text { Penggantian } \\
\text { meter air } \\
\text { pelanggan }\end{array}$ & $\begin{array}{l}\text { • Jumlah meter air } \\
\text { pelanggan yang } \\
\text { diganti; } \\
\text { •Jumlah pelanggan }\end{array}$ & $\begin{array}{l}\text { Laporan teknik (bagian } \\
\text { pelayanan pengaduan } \\
\text { pelanggan) }\end{array}$ \\
\hline \multicolumn{3}{|c|}{ D. Data aspek sumber daya manusia } \\
\hline Rasio pegawai & $\begin{array}{l}\text {-Jumlah pegawai; } \\
\text { •Jumlah pelanggan } \\
\text { (aktif dan non } \\
\text { aktif). }\end{array}$ & $\begin{array}{l}\text { Laporan administrasi } \\
\text { (bagian SDM) }\end{array}$ \\
\hline $\begin{array}{l}\text { Rasio diklat } \\
\text { pegawai }\end{array}$ & $\begin{array}{l}\text { • Jumlah pegawai } \\
\text { yang mengikuti } \\
\text { diklat; } \\
\text { •Jumlah pegawai }\end{array}$ & $\begin{array}{l}\text { Laporan administrasi } \\
\text { kepegawaian (bagian } \\
\text { SDM) }\end{array}$ \\
\hline $\begin{array}{l}\text { Rasio beban } \\
\text { diklat terhadap } \\
\text { beban pegawai }\end{array}$ & $\begin{array}{l}\text { - Jumlah beban } \\
\text { diklat; } \\
\text {-Jumlah beban } \\
\text { pegawai }\end{array}$ & $\begin{array}{l}\text { - Laporan administrasi } \\
\text { kepegawaian; } \\
\text { - Laporan keuangan }\end{array}$ \\
\hline
\end{tabular}

Selanjutnya, solvabilitas diartikan sebagai suatu ukuran untuk mengetahui kemampuan PDAM menjamin kewajibankewajiban jangka panjang dengan asetnya (Persamaan 5).

Laba bersih setelah pajak

$\overline{\text { Jumlah ekuaitas (modal + cadangan) }}$

dengan laba bersih setelah pajak adalah kelebihan seluruh pendapatan atas seluruh beban untuk satu periode tertentu (satu tahun) setelah dikurangi pajak penghasilan yang disajikan dalam laporan laba rugi dan jumlah ekuitas adalah jumlah modal ditambah cadangan atau aset dikurangi kewajiban.

\section{Beban operasi}

Pendapatan operasi

dengan beban operasi adalah seluruh beban usaha baik beban langsung usaha (beban sumber air, beban pengolahan air dan beban transmisi dan distribusi) maupun beban tidak langsung usaha (beban administrasi dan umum) (Rp) dan pendapatan operasi adalah seluruh pendapatan usaha yang meliputi pendapatan air dan pendapatan non air (Rp).

\section{Jumlah kas + Setara kas}

$\overline{\text { Jumlah kewajiban lancar }}$

dengan jumlah kas adalah seluruh jumlah uang kas yang ada baik yang berada di kas perusahaan (tunai) maupun yang ada di Bank, setara kas adalah surat berharga yang dimiliki yang secara seketika dapat diuangkan termasuk deposito, surat berharga, promes dan cek mundur (yang masuk dalam aset lancar) (Rp) dan jumlah kewajiban lancar adalah seluruh kewajiban yang harus dapat dilunasi dalam satu tahun buku (Rp). $\frac{\text { Jumlah penerimaan rekening air }}{\text { Jumlah rekening air }} \times 100 \%$

dengan jumlah penerimaan rekening air adalah penerimaan tunai (penerimaan melalui kas dan/atau melalui bank) dalam satu tahun buku atas volume air terjual (jumlah rekening air) (Rp) dan jumlah rekening air adalah seluruh jumlah tagihan kepada pelanggan PDAM sesuai DRD air selama satu tahun (DRD air terdiri atas harga air dan beban tetap) (Rp). Pengertian ini didasarkan bahwa penjualan air PDAM (pendapatan penjualan air) dicatat berdasarkan jumlah air yang dikonsumsi pelanggan pada saat transaksi terjadi, pelanggan tidak langsung membayar.

$\frac{\text { Jumlah asset }}{\text { Jumlah kewajiban }} \times 100 \%$

dengan jumlah aset adalah sumber daya yang dikuasai PDAM sebagai akibat dari peristiwa masa lalu dan dari manfaat ekonomi di masa depan diharapkan akan diperoleh entitas (Rp) dan jumlah kewajiban adalah jumlah kewajiban yang harus dibayar (Rp).

Selanjutnya untuk aspek pelayanan, yang dievaluasi adalah cakupan pelayanan teknis, pertumbuhan pelanggan, tingkat penyelesaian pengaduan, kualitas air pelanggan dan konsumsi air domestik. Pengertian dari cakupan pelayanan teknis adalah suatu ukuran untuk mengetahui berapa besar prosentase jumlah penduduk terlayani oleh PDAM dibanding dengan jumlah penduduk di wilayah pelayanan PDAM (Persamaan 6). Untuk pertumbuhan pelanggan, indikator ini digunakan untuk mengetahui berapa prosentase peningkatan jumlah pelanggan PDAM dalam satu periode (bulanan, triwulan, semester atau tahunan) (Persamaan 7). Sedangkan tingkat penyelesaian pengaduan merupakan ukuran untuk menilai respon atau tanggapan PDAM terhadap pengaduan pelanggannya (Persamaan 8). Selanjutnya, kualitas air pelanggan merupakan ukuran yang digunakan untuk mengetahui apakah kualitas air yang didistribusikan oleh PDAM kepada pelanggan telah memenuhi kualitas air minum seperti yang ditetapkan dalam Permenkes Nomor 492/MENKES/PER/V/2010 Tentang Persyaratan Kualitas Air Minum (Persamaan 9). Konsumsi air domestik merupakan ukuran yang digunakan untuk menggambarkan tingkat pemakaian air oleh pelanggan kategori domestik (rumah tangga) (Persamaan 10).

\section{$\frac{\text { Jumlah penduduk terlayani }}{\text { Jumlah penduduk di wilayah pelayanan }} \times 100 \%$}

dengan jumlah penduduk terlayani merupakan jumlah sambungan dikali rata-rata jiwa per KK (didasarkan pada data BPS), jumlah sambungan adalah jumlah sambungan aktif pada akhir periode penilaian dan jumlah penduduk di wilayah pelayanan merupakan jumlah penduduk di wilayah pelayanan teknis (wilayah yang ada dalam perencanaan)

$\frac{\text { Jml pelanggan periode ini }-J m l \text { pelanggan periode lalu }}{\text { Jumlah pelanggan periode lalu }} \times 100 \%$

dengan jumlah pelanggan periode ini adalah jumlah pelanggan total yang tercatat di dalam administrasi pelayanan pada akhir periode evaluasi (SR) dan jumlah pelanggan periode lalu adalah jumlah pelanggan total yang tercatat di dalam administrasi pelayanan pada akhir periode lalu (SR).

Jumlah pengaduan pelanggan yang tertangani Jumlah pengaduan $\times 100 \%$ 
dengan: jumlah pengaduan yang tertangani adalah banyaknya pengaduan pelanggan yang tercatat dan telah diselesaikan masalahnya dalam satu periode evaluasi kinerja dan jumlah pengaduan adalah banyaknya pengaduan dari pelanggan yang tercatat selama satu periode evaluasi kinerja.

$\frac{\text { Jumlah uji yang memenuhi syarat }}{\text { Jumlah yang diuji }} \times 100 \%$

dengan jumlah uji yang memenuhi syarat adalah banyaknya hasil uji kualitas (sampel) air di titik pelanggan yang telah memenuhi syarat kualitas air minum menurut PerMenKes Nomor 492/MENKES/PER/IV/2010 tentang Persyaratan Kualitas Air Minum dan jumlah sampel yang diuji adalah banyaknya pengambilan sampel yang harus dilakukan menurut ketentuan Permenkes Nomor 736/MENKES/PER/VI/2010.

\section{Air terjual ke pelanggan domestik}

dengan jumlah air terjual pelanggan domestik rata-rata $\left(\mathrm{m}^{3}\right.$ per bulan) adalah banyaknya air yang dikonsumsi oleh pelanggan domestik rata-rata per bulan dan jumlah pelanggan domestik adalah banyaknya pelanggan domestik yang masih aktif (SR).

Selanjutnya, untuk aspek operasional, yang dievaluasi adalah efisiensi produksi, air tak berekening, jam operasi layanan, tekanan air pada sambungan pelanggan dan penggantian meter air pelanggan. Efisiensi produksi (faktor pemanfaatan produksi) merupa-kan indikator yang digunakan untuk mengukur efisiensi sistem produksi (Persamaan 11). Sedangkan air tak berekening (ATR) merupakan selisih antara air yang masuk unit distribusi dengan air yang berekening dalam jangka waktu selama periode evaluasi (Persamaan 12). Sedangkan jam operasi layanan merupakan indikator untuk mengukur efisiensi sistem secara keseluruhan dan kaitannya dengan kontinuitas pelayanan (Persamaan 13). Tekanan air pada sambungan pelanggan merupakan indikator untuk mengukur jumlah pelanggan yang dilayani dengan tekanan sesuai dengan tekanan minimum yang ditentukan (Persamaan 14). Penggantian meter air pelanggan merupakan indikator untuk mengukur tingkat ketelitian/ akurasi meter air pelanggan (Persamaan 15).

\section{Realisasi produksi}

Kapasitas terpasang

dengan: realisasi produksi adalah volume air yang diproduksi secara riil oleh PDAM $\left(\mathrm{m}^{3}\right)$ dan kapasitas terpasang adalah kapasitas unit produksi PDAM yang terpasang sesuai dengan rencana (L/det)

$$
\frac{\text { Distribusi air }- \text { Air terjual }}{\text { Distribusi air }} \times 100
$$

dengan distribusi air adalah banyaknya air yang disalurkan kepada pelanggan melalui jaringan pipa distribusi selama periode evaluasi $\left(\mathrm{m}^{3}\right)$ dan air terjual adalah banyaknya air yang terpakai oleh pelanggan dan tercatat dalam Ikhtisar Rekening Air (IRA) selama periode evaluasi $\left(\mathrm{m}^{3}\right)$

\section{Waktu distribusi air ke pelanggan Periode evaluasi}

dengan: waktu distribusi air ke pelanggan adalah pelayanan distribusi air yang dapat disediakan kepada pelanggan selama periode evaluasi (hari) dan periode evaluasi adalah jumlah hari untuk melakukan evaluasi (hari)

$\frac{\text { Jumlah pelang gan terlayani }}{\text { Jumlah pelanggan }} \times 100 \%$

dengan: jumlah pelanggan terlayani dengan tekanan minimal 0,7 bar (SR) adalah banyaknya pelanggan yang memperoleh pelayanan tekanan air minimal $7 \mathrm{~m}$ kolom air pada waktu jam puncak dan jumlah pelanggan adalah banyaknya pelanggan aktif (SR).

Jumlah meter air pelangaan yang diganti

$$
\text { Jumlah pelanggan } \times 100 \%
$$

dengan: jumlah meter air yang diganti adalah banyaknya meter air pelanggan yang diganti selama periode evaluasi (SR) dan jumlah pelanggan adalah banyaknya pelanggan aktif (SR).

Untuk aspek sumber daya manusia, yang dievaluasi adalah rasio pegawai terhadap pelanggan, rasio diklat pegawai, rasio beban diklat terhadap beban pegawai. Rasio pegawai terhadap pelanggan menggambarkan tingkat efisiensi dan efektifitas penggunaan tenaga kerja untuk memberikan pelayanan kepada pelanggan (Persamaan 16). Rasio diklat (pendidikan dan pelatihan) pegawai merupakan indikator yang digunakan untuk mengukur kepedulian perusahaan dalam upaya meningkatkan efektivitas pegawai (Persamaan 17). Rasio beban diklat merupakan indikator yang digunakan untuk mengukur upaya perusahaan dalam hal peningkatan kompetensi pegawai (Persamaan 18)

Jumlah pegawai

$\overline{\text { Jumlah pelanggan } / 1000}$

dengan: jumlah pegawai adalah banyaknya pegawai yang tercatat sebagai pegawai tetap dan honorer, jumlah pelanggan adalah seluruh pelanggan PDAM.

$\frac{\text { Jumlah pegawai yang mengikuti Diklat (orang) }}{\text { Jumlah pegawai (orang) }} \times 100 \%$

dengan: jumlah pegawai yang mengikuti diklat adalah banyaknya pegawai yang tercatat mengikuti pendidikan dan latihan selama periode evaluasi (orang) dan jumlah pegawai adalah banyaknya pegawai yang tercatat sebagai pegawai tetap dan honorer (orang).

$\frac{\text { Jumlah beban diklat }}{\text { Jumlah beban pegawai }} \times 100 \%$

dengan: jumlah beban diklat adalah seluruh beban yang dikeluarkan oleh PDAM terkait dengan kegiatan pendidikan dan pelatihan pegawai (termasuk SPPD dan transportasi/akomodasi) (Rp) dan jumlah beban pegawai adalah seluruh beban pegawai yang tercatat sebagai pegawai tetap dan honorer (Rp).

Untuk tahapan penetapan status kinerja, bobot, standar dan nilai standar indikator kinerja merupakan angka-angka acuan yang digunakan untuk menetapkan status PDAM. Penentuan bobot, standard dan nilai standar untuk setiap indikator kinerja PDAM dijelaskan pada Tabel 2. 
Tabel 2

Bobot, standar dan nilai standar indicator kinerja PDAM [5]

\begin{tabular}{|c|c|c|c|}
\hline Indikator kerja & Bobot & Standar & $\begin{array}{l}\text { Nilai } \\
\text { standar }\end{array}$ \\
\hline \multicolumn{4}{|l|}{ A. Aspek keuangan } \\
\hline $\begin{array}{l}\text { Rentabilitas } \\
\text { - Return on } \\
\text { equity (ROE) }\end{array}$ & 0,05 & $\begin{array}{l}\geq 10(\%) \\
7-10(\%) \\
3-7(\%) \\
0-3(\%) \\
<0(\%)\end{array}$ & $\begin{array}{l}5 \\
4 \\
3 \\
2 \\
1\end{array}$ \\
\hline - Rasio operasi & 0,05 & $\begin{array}{l}\leq 0,5 \\
0,5-0,65 \\
0,65-0,85 \\
0,85-1,0 \\
>1,0\end{array}$ & $\begin{array}{l}5 \\
4 \\
3 \\
2 \\
1\end{array}$ \\
\hline \multicolumn{4}{|l|}{ Likuiditas } \\
\hline - Rasio kas & 0,05 & $\begin{array}{l}\geq 100(\%) \\
80-100(\%) \\
60-80(\%) \\
40-60(\%) \\
<40(\%)\end{array}$ & $\begin{array}{l}5 \\
4 \\
3 \\
2 \\
1\end{array}$ \\
\hline $\begin{array}{r}\text { - Efektifitas } \\
\text { penagihan }\end{array}$ & 0,05 & $\begin{array}{l}\geq 90(\%) \\
85-90(\%) \\
80-85(\%) \\
75-80(\%) \\
<75(\%)\end{array}$ & $\begin{array}{l}5 \\
4 \\
3 \\
2 \\
1\end{array}$ \\
\hline Solvabilitas & 0,05 & $\begin{array}{l}\geq 200(\%) \\
170-200(\%) \\
135-170(\%) \\
100-135(\%) \\
<100(\%)\end{array}$ & $\begin{array}{l}5 \\
4 \\
3 \\
2 \\
1 \\
\end{array}$ \\
\hline \multicolumn{4}{|l|}{ B. Aspek pelayanan } \\
\hline $\begin{array}{l}\text { Cakupan pelayanan } \\
\text { teknis }\end{array}$ & 0,05 & $\begin{array}{l}\geq 80(\%) \\
60-80(\%) \\
40-60(\%) \\
20-40(\%) \\
<20(\%)\end{array}$ & $\begin{array}{l}5 \\
4 \\
3 \\
2 \\
1\end{array}$ \\
\hline Pertumbuhan pelanggan & 0,05 & $\begin{array}{l}\geq 10(\%) \\
8-10(\%) \\
6-8(\%) \\
4-6(\%) \\
<4(\%)\end{array}$ & $\begin{array}{l}5 \\
4 \\
3 \\
2 \\
1\end{array}$ \\
\hline $\begin{array}{l}\text { Tingkat penyelesaian } \\
\text { pengaduan }\end{array}$ & 0,025 & $\begin{array}{l}\geq 80(\%) \\
60-80(\%) \\
40-60(\%) \\
20-40(\%) \\
<20(\%)\end{array}$ & $\begin{array}{l}5 \\
4 \\
3 \\
2 \\
1\end{array}$ \\
\hline Kualitas air pelanggan & 0,075 & $\begin{array}{l}\geq 80(\%) \\
60-80(\%) \\
40-60(\%) \\
20-40(\%) \\
<20(\%)\end{array}$ & $\begin{array}{l}5 \\
4 \\
3 \\
2 \\
1\end{array}$ \\
\hline Konsumsi air domestik & 0,05 & $\begin{array}{l}\geq 30\left(\mathrm{~m}^{3} / \mathrm{bl}\right) \\
25-30\left(\mathrm{~m}^{3} / \mathrm{bl}\right) \\
20-25\left(\mathrm{~m}^{3} / \mathrm{bl}\right) \\
15-20\left(\mathrm{~m}^{3} / \mathrm{bl}\right) \\
<15\left(\mathrm{~m}^{3} / \mathrm{bl}\right)\end{array}$ & $\begin{array}{l}5 \\
4 \\
3 \\
2 \\
1\end{array}$ \\
\hline \multicolumn{4}{|l|}{ C. Aspek operasi } \\
\hline $\begin{array}{l}\text { Efisiensi produksi (faktor } \\
\text { pemanfaatan produksi) }\end{array}$ & 0,07 & $\begin{array}{l}\geq 90(\%) \\
80-90(\%) \\
70-80(\%) \\
60-70(\%) \\
<60(\%)\end{array}$ & $\begin{array}{l}5 \\
4 \\
3 \\
2 \\
1\end{array}$ \\
\hline
\end{tabular}

Tabel 2 (Lanjutan)

Bobot, standar dan nilai standar indicator kinerja PDAM [5]

\begin{tabular}{|c|c|c|c|}
\hline Indikator kerja & Bobot & Standar & $\begin{array}{l}\text { Nilai } \\
\text { standar }\end{array}$ \\
\hline $\begin{array}{l}\text { Air tak berekening-ATR } \\
\text { (NRW) }\end{array}$ & 0,07 & $\begin{array}{l}\leq 25(\%) \\
25-30(\%) \\
30-35(\%) \\
35-40(\%) \\
>40(\%)\end{array}$ & $\begin{array}{l}5 \\
4 \\
3 \\
2 \\
1\end{array}$ \\
\hline Jam operasi layanan & 0,08 & $\begin{array}{l}21-24 \text { (jam) } \\
18-21 \text { (jam) } \\
16-18 \text { (jam) } \\
12-16 \text { (jam) } \\
<12 \text { (jam) }\end{array}$ & $\begin{array}{l}5 \\
4 \\
3 \\
2 \\
1\end{array}$ \\
\hline $\begin{array}{l}\text { Tekanan air pada } \\
\text { sambungan pelanggan }\end{array}$ & 0,065 & $\begin{array}{l}\geq 80(\%) \\
60-80(\%) \\
40-60(\%) \\
20-40(\%) \\
<20(\%)\end{array}$ & $\begin{array}{l}5 \\
4 \\
3 \\
2 \\
1\end{array}$ \\
\hline $\begin{array}{l}\text { Penggantian meter air } \\
\text { pelanggan }\end{array}$ & 0,065 & $\begin{array}{l}\geq 20(\%) \\
15-20(\%) \\
10-15(\%) \\
5-10(\%) \\
<5(\%)\end{array}$ & $\begin{array}{l}5 \\
4 \\
3 \\
2 \\
1\end{array}$ \\
\hline \multicolumn{4}{|c|}{ D. Aspek sumber daya manusia } \\
\hline $\begin{array}{l}\text { Rasio jumlah } \\
\text { pegawai/1000 } \\
\text { pelanggan }\end{array}$ & 0,07 & $\begin{array}{l}\text { Kota } \\
\leq 6 \text { (orang) } \\
6-8 \text { (orang) } \\
8-10 \text { (orang) } \\
10-12 \text { (orang) } \\
>12 \text { (orang) } \\
\text { Kabupaten } \\
\leq 8 \text { (orang) } \\
8-10 \text { (orang) } \\
10-12 \text { (orang) } \\
12-14 \text { (orang) } \\
>14 \text { (orang) }\end{array}$ & $\begin{array}{l}5 \\
4 \\
3 \\
2 \\
1\end{array}$ \\
\hline Rasio diklat pegawai & 0,04 & $\begin{array}{l}\geq 80(\%) \\
60-80(\%) \\
40-60(\%) \\
20-40(\%) \\
<20(\%)\end{array}$ & $\begin{array}{l}5 \\
4 \\
3 \\
2 \\
1\end{array}$ \\
\hline $\begin{array}{l}\text { Beban diklat terhadap } \\
\text { beban pegawai }\end{array}$ & 0,04 & $\begin{array}{l}\geq 10(\%) \\
7,5-10(\%) \\
5-7,5(\%) \\
2,5-5(\%) \\
<2,5(\%)\end{array}$ & $\begin{array}{l}5 \\
4 \\
3 \\
2 \\
1\end{array}$ \\
\hline
\end{tabular}

\section{Hasil dan Pembahasan}

Hasil evaluasi kinerja PDAM Tirta Jasa Kabupaten Lampung Selatan terhadap aspek keuangan selama kurun waktu 2014-2018 disajikan pada Tabel 3. Terlihat bahwa nilai indikator return on equity yang rendah sangat terkait dengan nilai ekuitas dari PDAM yang bernilai negatif serta nilai kas dan setara kas yang juga rendah. Nilai kas dan setara kas yang rendah tersebut terkait erat dengan beban operasional yang tinggi. Nilai kas dan setara kas yang rendah menjadikan nilai indikator rasio kas yang rendah pula. Oleh karena itu peningkatan pendapatan serta menurunkan beban operasional melalui efisiensi dan efektivitas beban akan dapat memberikan dampak signifikan pada peningkatan kinerja indikator return on equity, rasio operasi dan rasio kas. 
Tabel 3

Kinerja PDAM untuk aspek keuangan

\begin{tabular}{lllllll}
\hline \multirow{2}{*}{$\begin{array}{l}\text { Tahun } \\
\text { buku }\end{array}$} & \multicolumn{2}{l}{ Rentabilitas } & Likuiditas & Solvabilitas \\
\cline { 2 - 5 } & ROE & Rasio & Rasio & Efektifitas & perasi \\
kas (\%) & penagihan (\%) & \\
\hline 2014 & $-25,40$ & 1,20 & 17,10 & 92,70 & 160,30 \\
2015 & $-33,30$ & 1,20 & 19,80 & 100 & 147,90 \\
2016 & $-5,53$ & 1,10 & 1186,88 & 98,02 & 5606,14 \\
2017 & 12,20 & 0,81 & 667,45 & 91,82 & 2403,75 \\
2018 & $-0,34$ & 1,01 & 4256,10 & 93,64 & 18384,87 \\
\hline
\end{tabular}

Kemudian, hasil evaluasi kinerja PDAM Tirta Jasa Kabupaten Lampung Selatan terhadap aspek pelayanan selama kurun waktu 2014-2018 disajikan pada Tabel 4. Indikator pertumbuhan pelanggan erat kaitannya dengan kepuasan pelanggan yang berkorelasi dengan kualitas air yang diterima oleh pelanggan serta tingkat penyelesaian pengaduan. Kepuasan pelanggan berkorelasi pula dengan tingkat konsumsi air pelanggan. Korelasi tersebut menunjukkan bahwa bila pelanggan puas dengan pelayanan yang diberikan oleh PDAM maka tingkat konsumsi air akan tinggi atau sebaliknya.

Tabel 4

Kinerja PDAM untuk aspek pelayanan

\begin{tabular}{llllll}
\hline $\begin{array}{l}\text { Tahun } \\
\text { buku }\end{array}$ & $\begin{array}{l}\text { Cakupan } \\
\text { pelayanan } \\
(\%)\end{array}$ & $\begin{array}{l}\text { Pertumbuh- } \\
\text { an pelang- } \\
\text { gan (\%) }\end{array}$ & $\begin{array}{l}\text { Tingkat } \\
\text { penyelesaian } \\
\text { pengaduan } \\
(\%)\end{array}$ & $\begin{array}{l}\text { Kualitas air } \\
\text { pelanggan } \\
(\%)\end{array}$ & $\begin{array}{l}\text { Konsumsi } \\
\text { air } \\
\text { domestik } \\
\left(\mathrm{m}^{3} / \mathrm{bln}\right)\end{array}$ \\
\hline 2014 & 54,60 & 6,30 & 87,20 & - & 15,70 \\
2015 & 56,10 & 3,00 & 100 & - & 15,20 \\
2016 & 57,30 & 3,74 & 97,79 & 62,50 & 15,02 \\
2017 & 61,33 & 8,39 & 100 & 12,50 & 15,12 \\
2018 & 65,54 & 4,61 & 100 & 22,73 & 13,88 \\
\hline
\end{tabular}

Selanjutnya, untuk evaluasi kinerja PDAM Tirta Jasa Kabupaten Lampung Selatan terhadap aspek operasi selama kurun waktu 2014-2018 disajikan pada Tabel 5.

Tabel 5

Kinerja PDAM untuk aspek operasi

\begin{tabular}{llllll}
\hline $\begin{array}{l}\text { Tahun } \\
\text { buku }\end{array}$ & $\begin{array}{l}\text { Efisiensi } \\
\text { produksi } \\
(\%)\end{array}$ & $\begin{array}{l}\text { Tingkat } \\
\text { hilang } \\
\text { air }(\%)\end{array}$ & $\begin{array}{l}\text { Jam } \\
\text { layanan/ } \\
\text { hari }\end{array}$ & $\begin{array}{l}\text { Tekanan } \\
\text { sambungan } \\
(\%)\end{array}$ & $\begin{array}{l}\text { Penggantian } \\
\text { meter air } \\
(\%)\end{array}$ \\
\hline 2014 & 37,30 & 26,50 & 15 & 80,00 & 3,50 \\
2015 & 38,80 & 26,20 & 15 & 81,00 & 2,50 \\
2016 & 28,52 & 26,91 & 15 & 81,08 & 1,29 \\
2017 & 31,92 & 25,23 & 14 & 85,76 & 1,60 \\
2018 & 31,08 & 26,10 & 16 & 84,87 & 2,79 \\
\hline
\end{tabular}

Dari Tabel 5 terlihat bahwa indikator penggantian dan (atau) kalibrasi meter air pelanggan PDAM Tirta Jasa Kabupaten Lampung Selatan selama kurun waktu 2014-2018 paling tinggi hanya mencapai 3,50\% pada tahun 2014. Indikator ini memiliki korelasi negatif dengan tingkat kehilangan air. Jumlah penggantian meter air yang rendah biasanya memberikan tingkat kehilangan air yang tinggi.

Untuk hasil evaluasi kinerja PDAM Tirta Jasa Kabupaten Lampung Selatan terhadap aspek sumber daya manusia selama kurun waktu 2014-2018 disajikan pada Tabel 6 . Permasalahan utama kinerja PDAM aspek sumber daya manusia adalah rasio beban diklat terhadap beban pegawai masih sangat rendah rata-rata $<2,5 \%$. Adanya permasalahan ini dikarenakan alokasi biaya diklat minim dan program diklat yang diikuti sedikit, hal ini disebabkan salah satunya adalah program diklat belum menjadi prioritas.
Tabel 6

Kinerja PDAM untuk aspek SDM

\begin{tabular}{llll}
\hline $\begin{array}{l}\text { Tahun } \\
\text { buku }\end{array}$ & $\begin{array}{l}\text { Rasio jumlah } \\
\text { pegawai/1000 } \\
\text { pelanggan }\end{array}$ & $\begin{array}{l}\text { Rasio diklat } \\
\text { pegawai (\%) }\end{array}$ & $\begin{array}{l}\text { Rasio beban diklat } \\
\text { terhadap beban pegawai } \\
(\%)\end{array}$ \\
\hline 2014 & 10,70 & 11,50 & 0,50 \\
2015 & 10,20 & 10,00 & 0,40 \\
2016 & 11,30 & 8,70 & 1,06 \\
2017 & 13,30 & 48,86 & 0,12 \\
2018 & 12,71 & 45,45 & 0,20 \\
\hline
\end{tabular}

Dari hasil evaluasi kinerja PDAM berdasarkan aspek-aspek tersebut di atas, maka kategori kinerja PDAM Tirta Jasa Kabupaten Lampung Selatan selama kurun waktu 20142018 disajikan pada Tabel 7. Terlihat bahwa sebagian besar hasilnya kategori kurang sehat, untuk itu diperlukan beberapa alternatif strategi guna meningkatkan kinerja PDAM Tirta Jasa Kabupaten Lampung Selatan.

\section{Tabel 7}

Kategori kinerja PDAM di wilayah penelitian (2014-2018)

\begin{tabular}{|c|c|c|c|c|c|c|}
\hline \multirow{2}{*}{$\begin{array}{l}\text { Tahun } \\
\text { buku }\end{array}$} & \multicolumn{4}{|c|}{ Nilai Kinerja Per Aspek } & \multirow{2}{*}{$\begin{array}{l}\text { Total } \\
\text { nilai } \\
\text { kerja }\end{array}$} & \multirow{2}{*}{ Kategori } \\
\hline & Keuangan & Pelayanan & Operasi & SDM & & \\
\hline 2014 & 0,53 & 0,60 & 0,90 & 0,29 & 2,32 & Kurang \\
\hline 2015 & 0,53 & 0,50 & 0,90 & 0,29 & 2,22 & Kurang \\
\hline 2016 & 0,81 & 0,73 & 0,90 & 0,29 & 2,73 & Kurang \\
\hline 2017 & 1,14 & 0,70 & 0,90 & 0,30 & 3,04 & Sehat \\
\hline 2018 & 0,81 & 0,63 & 0,90 & 0,30 & 2,64 & Kurang \\
\hline
\end{tabular}

\section{Kesimpulan}

Dalam rangka melaksanakan pengadaan air bersih yang terbaik bagi warga, maka kinerja PDAM Tirta Jasa perlu dievaluasi agar tercipta kelembagaan yang semakin prima. Hasil evaluasi kinerja PDAM Tirta Jasa dari tahun 2014-2018 yang selalu masuk dalam kategori kurang sehat kecuali tahun 2017, perlu mendapatkan perhatian agar untuk tahuntahun yang akan datang kinerja PDAM Tirta Jasa dapat meningkat. Hasil penilaian kinerja PDAM Tirta Jasa Kabupaten Lampung Selatan terhadap keempat aspek tersebut, maka aspek sumber daya manusia perlu ditingkatkan agar kinerja PDAM Tirta Jasa dapat meningkat.

\section{Daftar Pustaka}

[1] Pratama, F.A., Rahdriawan, M., Wahyono, H., Damayanti, M. and Artiningsih, A.: Estimasi daya beli air PDAM masyarakat permukiman kumuh Kelurahan Mangkang Wetan Semarang. Jurnal Riptek, 14(2), 2020,143-152.

[2] Damayanti, A.P., Sumaryati, S.: Pengaruh kompensasi dan motivasi kerja terhadap kinerja karyawan perusahaan daerah air minum (PDAM) Surakarta. Jupe-Jurnal Pendidikan Ekonomi, 2(1), 2013.

[3] Wiratama, I. N. J. A., Sintaasih, D.K.: Pengaruh kepemimpinan, diklat, dan disiplin kerja terhadap kinerja karyawan PDAM Tirta Mangutama Kabupaten Badung. Jurnal Manajemen, Strategi Bisnis, dan Kewirausahaan, 7(2), 2013, 126-134.

[4] Huda, A.Z. 2013. Analisis Kinerja Dengan Pendekatan Balance Scorecard (Studi Kasus PDAM Tirta Dharma Kabupaten Klaten). Jurnal Publikasi Universitas Muhammadyah Surakarta

[5] Badan Peningkatan Penyelenggaran Sistem Penyediaan Air Minum. Petunjuk Teknis Penilaian Kinerja PDAM, 2010. http://bppspam.com/ 